\section{Acreage Increase Due to Slope}

\section{E. WILLIAM ANDERSON}

State Range Conservationist

Soil Conservation Service.

Portland, Oregon.

Acreage usually is determined from a map. Maps represent plane or horizontal distances and acreages. Actual surface areas exceed map acres according to steepness of the terrain. Table 1 shows the degree to which actual surface acres exceed map acres according to slope gradient.

Areas having 40 to $75 \%$ slope gradients are common in the mountainous West. Surface acres on these steep areas exceed map acreages by 8 to $25 \%$. Very steep areas having slope gradients in excess of $75 \%$ are less common but do occur over sizeable areas. They are important locally as watersheds, game ranges, and, to a lesser degree, as livestock ranges. They often provide excellent scenery.

It is not uncommon among resource workers and others to encounter those who do not understand "percent" slope. To them, for example, a $100 \%$ slope is straight up-90. Actually, a $100 \%$ slope has a vertical rise of one foot for each foot of horizontal distance. In construction it is called a one-toone slope. It is a $45^{\circ}$ slope. Figure 1 graphically illustrates how slopes of various gradients look when drawn in cross-section.

Acreage increase due to slope becomes implicated in resource planning and management of very steep areas. For example, actual surface acreage might be important for predicting such items as the amount of potential water represented by a snowpack.
Table 1. Percent slope, corresponding degree of slope, and percent increase in surface acres over horizontal map acreage.

\begin{tabular}{|c|c|c|c|}
\hline Slope (\%) & $\begin{array}{r}\text { Slo } \\
\text { (Deg }\end{array}$ & $\begin{array}{l}\text { pe } \\
\text { rees) }\end{array}$ & $\begin{array}{l}\% \text { Acreage } \\
\text { increase }^{1}\end{array}$ \\
\hline 5 & $2^{\circ}$ & $52^{\prime}$ & 0 \\
\hline 10 & 5 & 43 & 0 \\
\hline 15 & 8 & 32 & 1 \\
\hline 20 & 11 & 19 & 2 \\
\hline 25 & 14 & 02 & 3 \\
\hline 30 & 16 & 42 & 4 \\
\hline 35 & 19 & 17 & 6 \\
\hline 40 & 21 & 48 & 8 \\
\hline 45 & 24 & 14 & 10 \\
\hline 50 & 26 & 34 & 12 \\
\hline 55 & 28 & 49 & 14 \\
\hline 60 & 30 & 58 & 17 \\
\hline 65 & 33 & 01 & 19 \\
\hline 70 & 34 & 59 & 22 \\
\hline 75 & 36 & 52 & 25 \\
\hline 80 & 38 & 40 & 28 \\
\hline 85 & 40 & 22 & 31 \\
\hline 90 & 41 & 59 & 35 \\
\hline 95 & 43 & 32 & 38 \\
\hline 100 & 45 & 00 & 41 \\
\hline 125 & 51 & 20 & 60 \\
\hline 150 & 56 & 19 & 80 \\
\hline 175 & 60 & 15 & 102 \\
\hline 200 & 63 & 23 & 123 \\
\hline
\end{tabular}

${ }^{1}$ Increase surface acres over horizontal map acres.

Surface acreage is one of several factors involved in the amount of grazing use that is actualy obtained from very steep rangelands or grazed woodlands under good management. Cook (1966) concluded that actual use is the most accurate method of determining the amount of grazing obtainable on a particular mountain slope.

Also involved is the question of whether or not very steep slopes produce more vegetation per unit of horizontal area than do moderate slopes. Some accept the concept that the spatial requirement of plants is dependent upon vertical spacing rather than slope surface

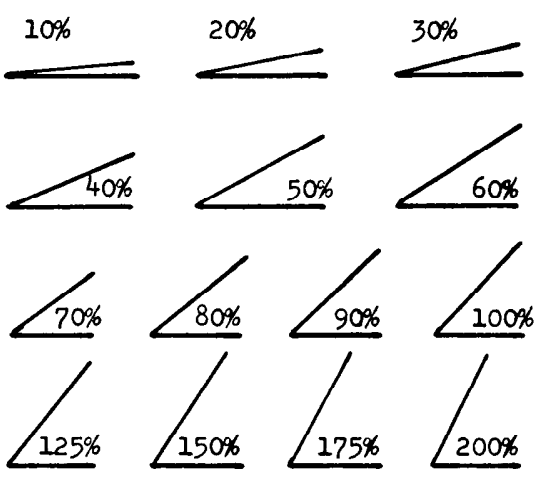

FIG. 1. Graphic presentation of slope steepness as related to percent slope.

area. A good example often cited is the way trees grows vertically on all slopes and can tolerate only so much crowding together irrespective of slope gradient. Whether or not this concept applies to herbaceous vegetation on slopes steep enough to significantly increase the actual acreage over map acreage might be debated. White (1967), studying purple needlegrass (Stipa pulchra Hitchc.) on slopes between 5 and 50\% gradient, found that basal area intercept and quadrat frequency were greater on steep slopes than on moderate slopes. On the other hand, he found that clipped weights for all live plants were greater on the gentle slopes. Since "steep" slopes he studied were less than $50 \%$ gradient, they increased map acreage less than $12 \%$. One might question whether or not the same results would have been obtained in regard to herbage yields on very steep slopes that increase map acreage in excess of $20 \%$.

Forage on very steep slopes usually is considered to be less available than on moderate slopes for cattle grazing (Mueggler, 1965; and Cook, 1966). This probably does not apply to grazing by wildlife whose natural habitat includes very stecp 


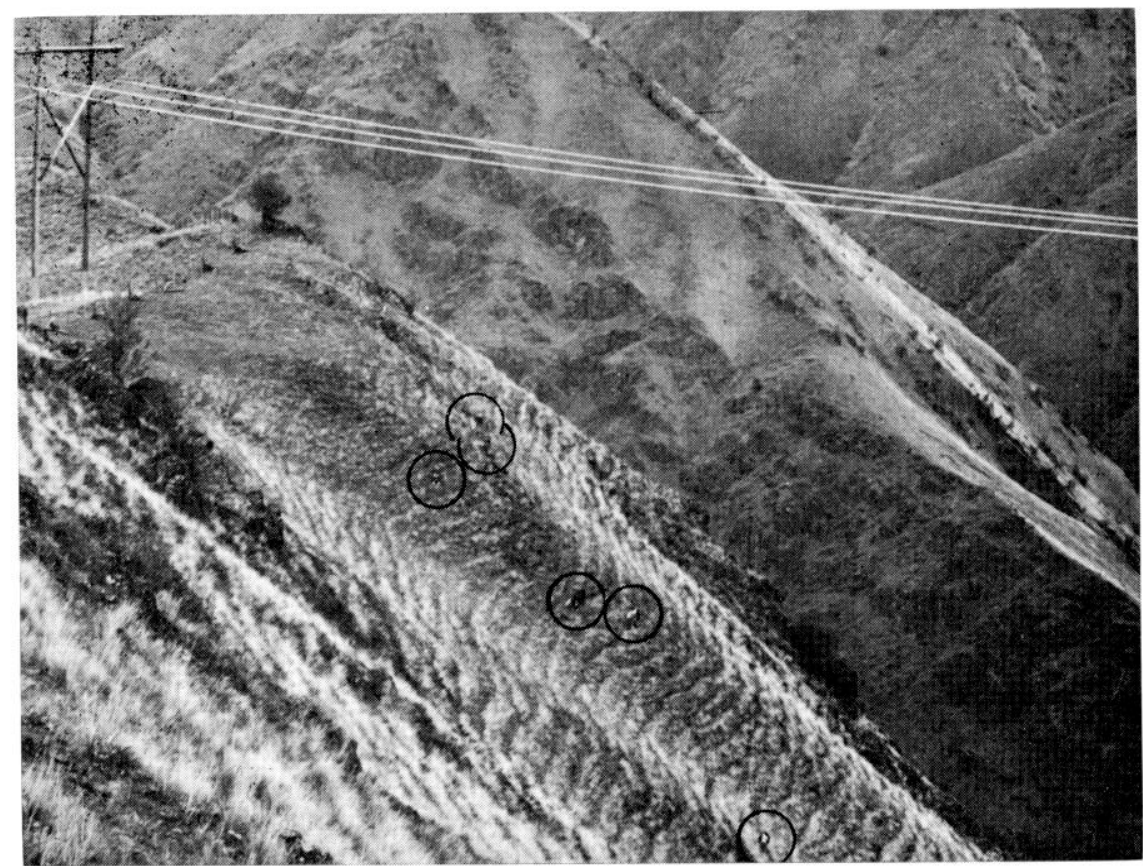

Fig. 2. Cattle grazing on a 90 percent slope in the Imnaha-Hells Canyon rangelands of northeastern Oregon.

areas. It also applies to a lesser degree to grazing by cattle that are accustomed to very steep terrain, and to situations where an entire pasture consists of very steep land.
Figure 2 shows Hereford cattle (circled) grazing a slope having $90 \%$ gradient. This is a common sight in the famous Imnaha-Hells Canyon rangelands of northeastern
Oregon where slopes this steep, and steeper, extend about 4,000 ft upward from the river. The cattle that graze from bottom to top and between the rimrocks on these precipitous slopes are raised locally on this kind of terrain. Flat-land cattle would probably starve to death on these very steep but very good rangelands.

It is imperative in resource planning and management of very steep areas to fully consider and provide for stability of the resource. Some very steep sites remain stable under judicious grazing use. Others are affected detrimentally merely by having animals walk across them.

\section{Literature Cited}

CoOK, C. Wayne. 1966. Factors affecting utilization of mountain slopes by cattle. J. Range Manage. 19:200204.

Mueggler, Walter F. 1965. Cattle distribution on steep slopes. J. Range Manage. 18:255-257.

White, Keith L. 1967. Native bunchgrass (Stipa pulchra) on Hastings Reservation, California. Ecology 48: 949-955. 